\title{
Article
}

|||||||||||||||||||||||||||||||||||||||||||

\section{Development of a Real-time Autoradiography System to Analyze the Movement of the Compounds Labeled with $\beta$-ray Emitting Nuclide in a Living Plant}

\author{
Hiroki RaI*, Satomi Kanno*, Yoshitake Hayashi*, \\ Tomoyuki OHYA ${ }^{*}$, Naoto $\mathrm{NIHEI}^{*}, * *$ and Tomoko M. NAKANISHI ${ }^{*}$ \\ * Laboratory of Radioplant Physiology, Department of Applied Biological Chemistry, \\ Graduate School of Agricultural and Life Sciences, The University of Tokyo \\ 1-1-1 Yayoi, Bunkyo-ku, Tokyo 113-8657, Japan \\ **Fukushima Agricultural Technology Center
}

116 Shimonakamichi, Takakura, Hiwada-machi, Koriyama-shi, Fukushima Pref. 963-0531, Japan

Received January 28, 2008

\begin{abstract}
Real-time imaging analysis in a living plant allows studying the mechanism of chemical transport or signal transduction more in detail. We present the real-time autoradiography system to analyze the movement of $\beta$-ray emitters in a living plant. The system was consisted of a FOS (a fiber optic plate deposited with CsI (Ti) scintillator) and a GaAsP imaging intensifier unit. Though the resolution is about the same as that of an imaging plate (IP), the sensitivity was more than 10 times higher than that of an IP. Using this system, ${ }^{32} \mathrm{P}$ movement in a young leaf of soybean was analyzed when ${ }^{32} \mathrm{P}$ was supplied from the root.
\end{abstract}

Key Words : real-time autoradiography, beta ray imaging, fiber optic plate, imaging plate, succsessive imaging analysis, phosphorus-32

\section{Introduction}

Real-time imaging analysis of target chemicals in a living plant allows studying the mechanism of transport form cell to cell or signal transduction more in detail. Generally, radioisotope-labeled compounds were used to analyze the movement of the chemicals and performed to show the distribution of the chemicals in the organisms and tissues as autoradiography images ${ }^{1}$. However, autoradiography using an X-ray film or an imaging plate (IP) requires to fix the plant in a cassette during the exposure, therefore, further experiment using the same plant cannot be performed.

There are some reports carrying out real- time radioisotope imaging with semiconductor detector in a living thing ${ }^{2), 3)}$. Especially, for analyzing chemical transport in a living plant, Positron Emitting Tracer Imaging System (PETIS), employing positron emitters, was developed at Japan Atomic Energy Agency (JAEA). Using this system, chemicals labeled with ${ }^{11} \mathrm{C},{ }^{13} \mathrm{~N},{ }^{15} \mathrm{O}$, ${ }^{18} \mathrm{~F}$, which were prepared by an accelerator, were applied to a plant and some chemical movements, such as $\mathrm{H}_{2} \mathrm{O}\left(\mathrm{H}_{2}{ }^{15} \mathrm{O}\right), \mathrm{NO}_{3}{ }^{-}\left({ }^{13} \mathrm{NO}_{3}{ }^{-}\right)$, $\mathrm{NH}_{4}{ }^{+}\left({ }^{13} \mathrm{NH}_{4}{ }^{+}\right)$and methionine $\left({ }^{11} \mathrm{C}\right.$-methionine), were analyzed ${ }^{4), 5)}$. However, in the case of PETIS, the resolution is limited to several $\mathrm{mm}$, because of measuring a pair of $\gamma$-rays produced by annihilation of positron. Most of positron emitters have extremely short half-lives and it requires a special accelerator for preparation. 
Considering the quantification as well as the resolution of the image, we tried to develop a real-time autoradiography system using $\beta$-ray emitters which are commercially available. In our system, the $\beta$-ray, emitted from the sample was converted to light by a solid scintillator and this very weak light was detected by a highly sensitive camera.

Recently, there was a remarkable development of a CCD or an image intensifying camera and even a single photon was able to be detected with high efficiency. These cameras were applied to image fluorescent or luminescent molecules in the tissues. Now fluorescent techniques allow not only imaging the static distribution of the chemicals in a cell but also getting successive images of the focused single protein labeled with fluorescent probes such as GFP, etc.

Therefore, we applied one of these highly sensitive camera, a GaAsP imaging intensifier unit, cooled with water (C8600-04 Hamamatsu photonics, Co.) to detect the light from FOS (Fiber optic plate with scintillator, J6677 Hamamatsu photonics, Co.), which are applied for digital X-ray imaging, to convert $\beta$-rays to visible light.

\section{Materials and Methods}

\section{$2 \cdot 1$ Outline of the system}

$\beta$-ray from a radioisotope in a living plant was converted to light by a $\mathrm{CsI}(\mathrm{Ti})$ scintillator, and the very weak light was lead to the GaAsP semiconductor surface by lens. After the light was converted to electrons at GaAsP semiconductor, MCP (micro channel plate) in an imaging intensifier unit amplified the electrons by acceleration in an electric field caused by high voltage to capillaries, in which the electrons clash to the opposite side to emit more elec-

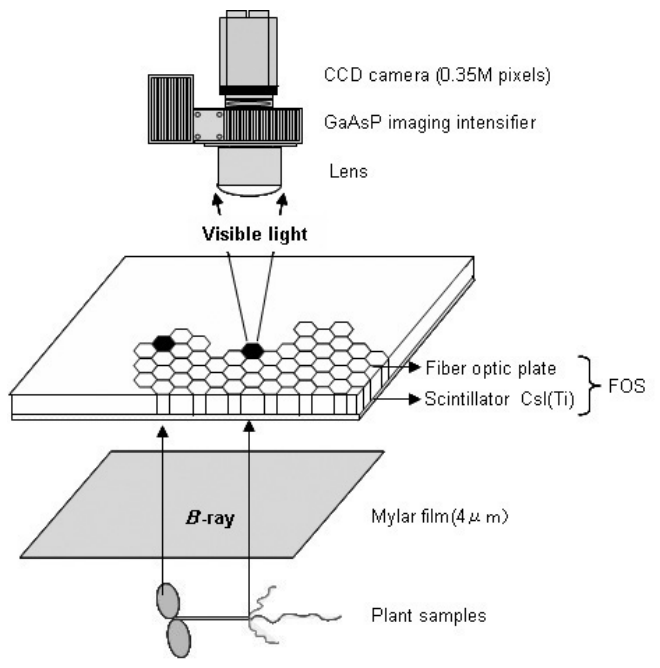

Fig. 1 Outline of real-time autoradiography system.

trons. After amplification processes, an image was produced on the fluorescent surface and this image was detected by a CCD camera (0.35 M pixels) (Fig. 1). The measurement was performed in a dark box, since the light intensity converted by scintillator was very weak.

\section{$2 \cdot 2$ Sensitivity of the system}

In order to measure the sensitivity of the system, ${ }^{32} \mathrm{P}\left(\mathrm{H}_{3}{ }^{32} \mathrm{PO}_{4}\right.$, Parkin Elmer $)$ solution was used. Two $\mu \mathrm{L}$ of the diluted solution was mounted on a membrane filter (Durapore membrane filters, Millipore) and this filter was covered with a myler film ( $4 \mu \mathrm{m}$, in thickness) and the CsI scintillator deposited side of FOS was placed on the sample. The fluorescent light converted by the scintillator was detected by a GaAsP imaging intensifier unit. The high voltage of the imaging intensifier was 255 and lower noise was cut by setting the threshold 10 (the parameters were in arbitrary units). The covered area of the image was $5 \mathrm{~cm} \times 5 \mathrm{~cm}$. The integration image was obtained every 10 
May 2008 H. Rai et al. : Development of a real-time autoradiography system to analyze the movement of the compounds labeled with $\beta$-ray emitting nuclide in a living plant

sec, $30 \mathrm{sec}, 1 \mathrm{~min}, 3 \mathrm{~min}, 5 \mathrm{~min}$ and $10 \mathrm{~min}$.

To compare the sensitivity of this system, the same sample was exposed to an imaging plate (IP, BAS-MS2340, FujiFilm, Co.) in a cassette. After $1 \mathrm{~min}, 5 \mathrm{~min}, 10 \mathrm{~min}, 30 \mathrm{~min}, 60 \mathrm{~min}$ and $120 \mathrm{~min}$, the images on the IP was scanned by a scanner (Fla-5000, FujiFilm, Co.), where the resolution in the scanning image was set as $25 \mu \mathrm{m}$ and scanning sensitivity was set as IP S mode.

$2 \cdot 3$ Comparison of the images of our system with those of an IP

Seeds of a soybean plant (Glycin Max. cv. Enlei) were germinated in vermiculite and were grown in a Hoagland culture solution in a growth chamber at $28{ }^{\circ} \mathrm{C}$ under $16 \mathrm{~h}$ light and $8 \mathrm{~h}$ dark cycles, for 2 weeks. Then, the soybean plant was replaced to the Hoagland solution (P : $10 \mu \mathrm{M}, 5 \mathrm{MBq} / 100 \mathrm{~mL}$ ) added with ${ }^{32} \mathrm{P}$ solution was added to and cultured further for 24 hours.

After $24 \mathrm{~h}$, center leaf of the first expanded trifoliate was harvested and ${ }^{32} \mathrm{P}$ distribution image in the leaf was obtained both by our realtime autoradiography system (the high voltage of the imaging intensifier was 230 with threshold setting) and by an IP (the measurement condition is same above). The measuring time of our system was $10 \mathrm{sec}, 30 \mathrm{sec}, 1 \mathrm{~min}$ and $5 \mathrm{~min}$. In the case of an IP, exposure was performed for $1 \mathrm{~min}, 5 \mathrm{~min}, 15 \mathrm{~min}$ and $30 \mathrm{~min}$.

$2 \cdot 4$ Real-time images of ${ }^{32} \mathrm{P}$ in a soybean plant leaves

A soybean seedling grown for 2 weeks in Hoagland culture solution was transferred to the tube containing $20 \mathrm{~mL}$ Hoagland solution with ${ }^{32} \mathrm{P}\left(\mathrm{P}: 10 \mu \mathrm{M},{ }^{32} \mathrm{P}: 25 \mathrm{MBq} / 100 \mathrm{~mL}\right)$. The FOS was placed on the leaf and ${ }^{32} \mathrm{P}$ uptake

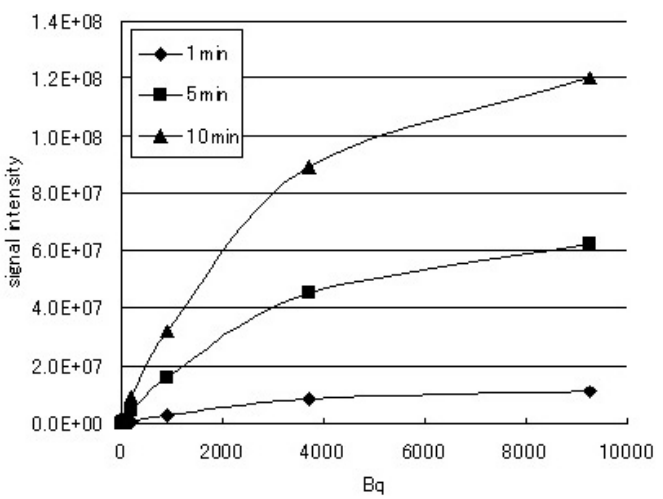

Fig. 2 Linearity of calibration curve of real-time autoradiography system. ( ${ }^{32} \mathrm{P}$ in high radioactivity range)

manner in the leaf was monitored by our realtime autoradiography system. The image was integrated every 2 minutes and 500 images were obtained successively.

\section{Results and Discussion}

$3 \cdot 1$ Sensitivity of the real-time autoradiography system

The dynamic range of our system was found less than about $1000 \mathrm{~Bq}$, where the linearity between signal intensity and radioactivity was shown. When the radioactivity was more than $1000 \mathrm{~Bq}$, the detection efficiency was drastically decreased (Fig. 2). However, when the radioactivity was low, especially lower than 100 $\mathrm{Bq}$, the correlation coefficient of the calibration curve was very high, higher than $R^{2}=0.99$ in every measuring time (Fig. 3).

When the detection limit of the radioactivity was set twice as high as background intensity, i.e. $\mathrm{S} / \mathrm{N}=2,1.85 \mathrm{~Bq}$ was able to detected by 1 minute measurement and $0.37 \mathrm{~Bq}$ by $3 \mathrm{~min}$ utes measurement, respectively (Fig. 4).

In the case of an IP, the dynamic range was very wide and the linearity was shown until about $10000 \mathrm{~Bq}$ during 1 to 60 minutes meas- 


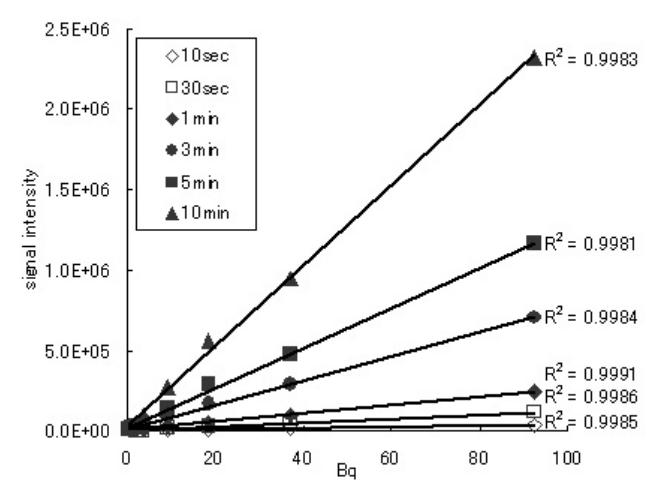

Fig. 3 Linearity of calibration curve of real-time autoradiography system. $\left({ }^{32} \mathrm{P}\right)$

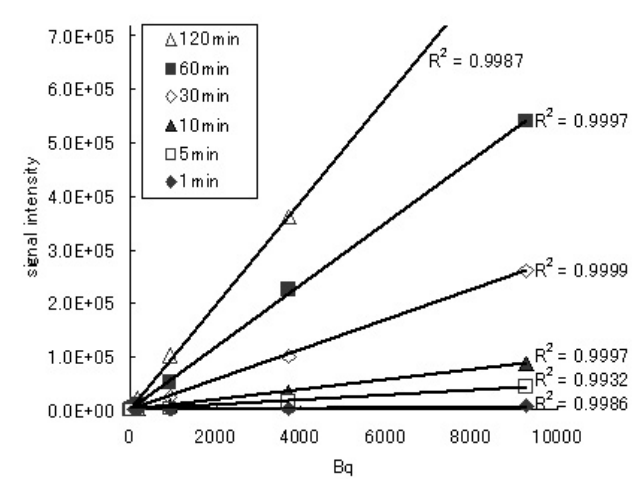

Fig. 5 Linearity of calibration curve of an imaging plate. $\left({ }^{32} \mathrm{P}\right)$

urement(Fig. 5). The detection limit was found to $92.5 \mathrm{~Bq}, 37 \mathrm{~Bq}$ and $18.5 \mathrm{~Bq}$ in 1,5 and $10 \mathrm{~min}$ utes exposure, respectively (Fig. 6).

These results showed that the sensitivity of our system was more than 50 and 10 times higher in 1 and 5 minute measurement than those by an IP.

The highly sensitive imaging and quantification of the radioactivity was able to perform with our system, especially in the low level of the radioactivity, indicating that our system was suitable to detect or image weak radioactivity in a plant tissue.

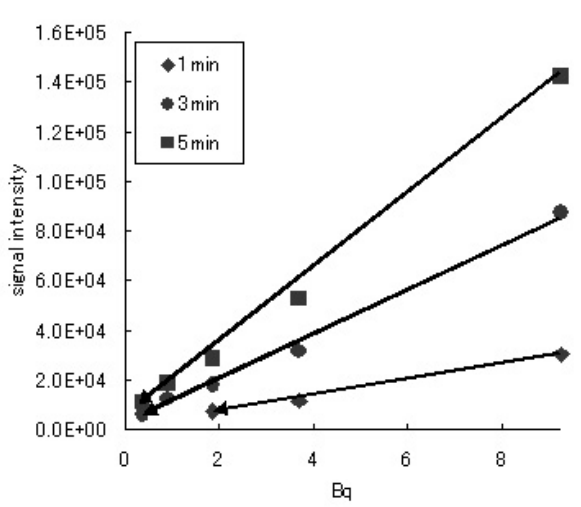

Fig. 4 Linearity of calibration curve of real-time autoradiography system. $\left({ }^{32} \mathrm{P}\right.$ in low radioactivity range)

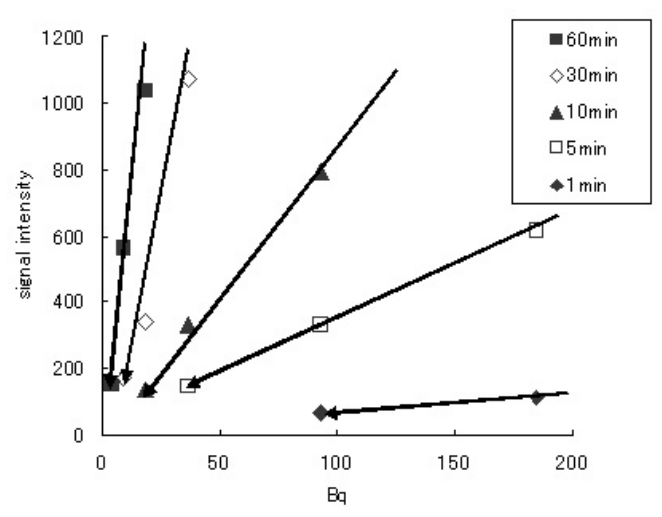

Fig. 6 Linearity of calibration curve of an imaging plate. ( ${ }^{32} \mathrm{P}$ in low radioactivity range)

$3 \cdot 2$ Comparison of the images of our system with those of an IP

With our system the leaf veins were able to detect as early as 10 seconds measurement. Therefore, after 1 to 3 minutes, the resolution of the image was high enough to perform image analysis and quantitative radioactivity measurement, where the data depth of the image was more than 8 bit (Fig. 7). In the case of an IP, the veins in the leaf were not able to detect after 1 minute, and at least 5 minutes exposure was needed to identify the leaf veins. In our system we could find out the veins in 10 

of the compounds labeled with $\beta$-ray emitting nuclide in a living plant

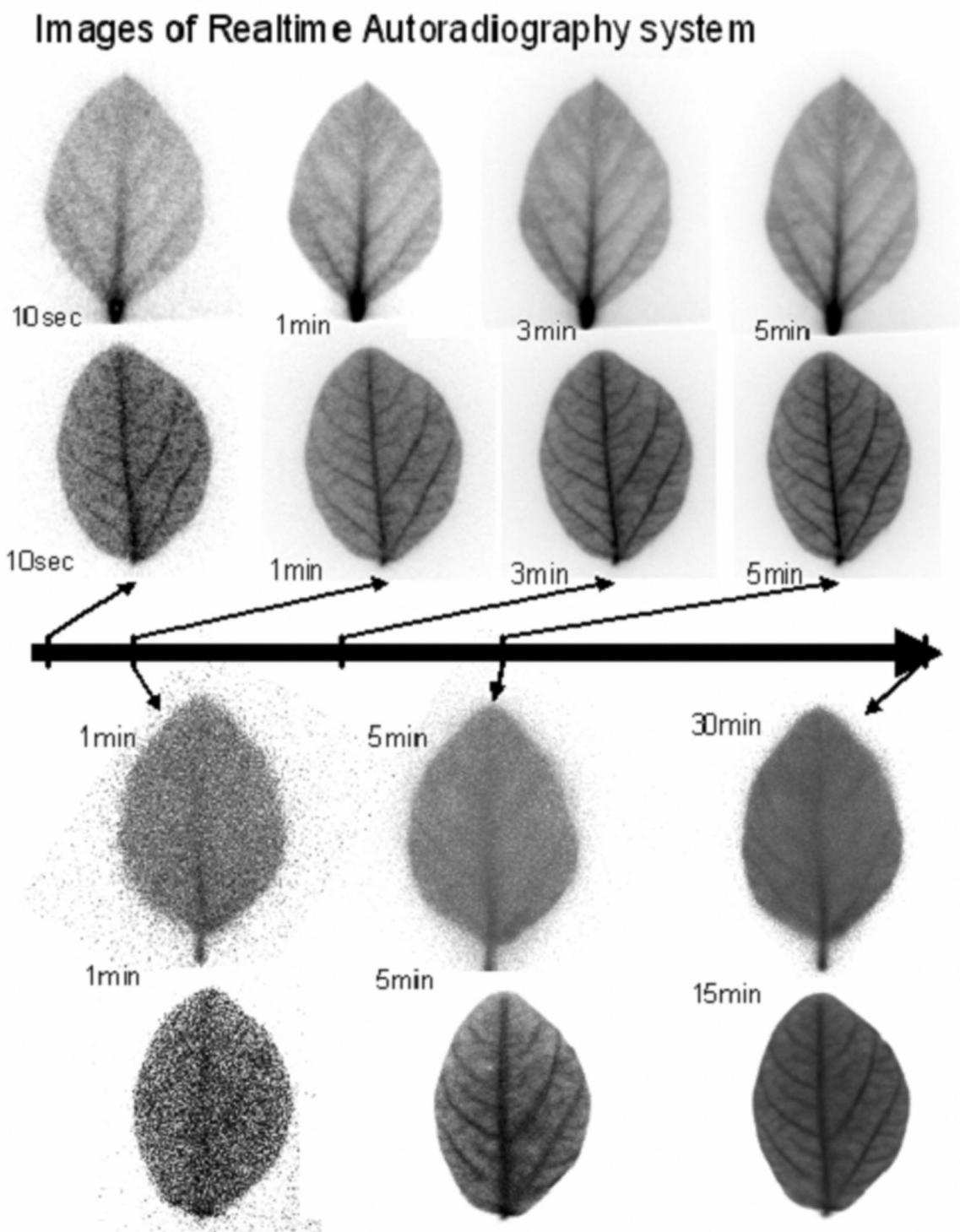

Images of Imaging Plate

Fig. 7 Comparison of the images acquired by real-time autoradiography system with those by an imaging plate.

times shorter time than that needed for an IP. The resolution of the image with our system in the area of $5 \mathrm{~cm} \times 5 \mathrm{~cm}$ was the same as that of IP (Image readout with $25 \mu \mathrm{m}$ resolution).
$3 \cdot 3$ Real-time images of ${ }^{32} \mathrm{P}$ uptake in a soybean plant leaves

The successive ${ }^{32} \mathrm{P}$ uptake images in the first leaf were shown in Fig. 8. From these images it was able to analyze the increasing manner of the radioactivity in any area of the leaf. At first, 


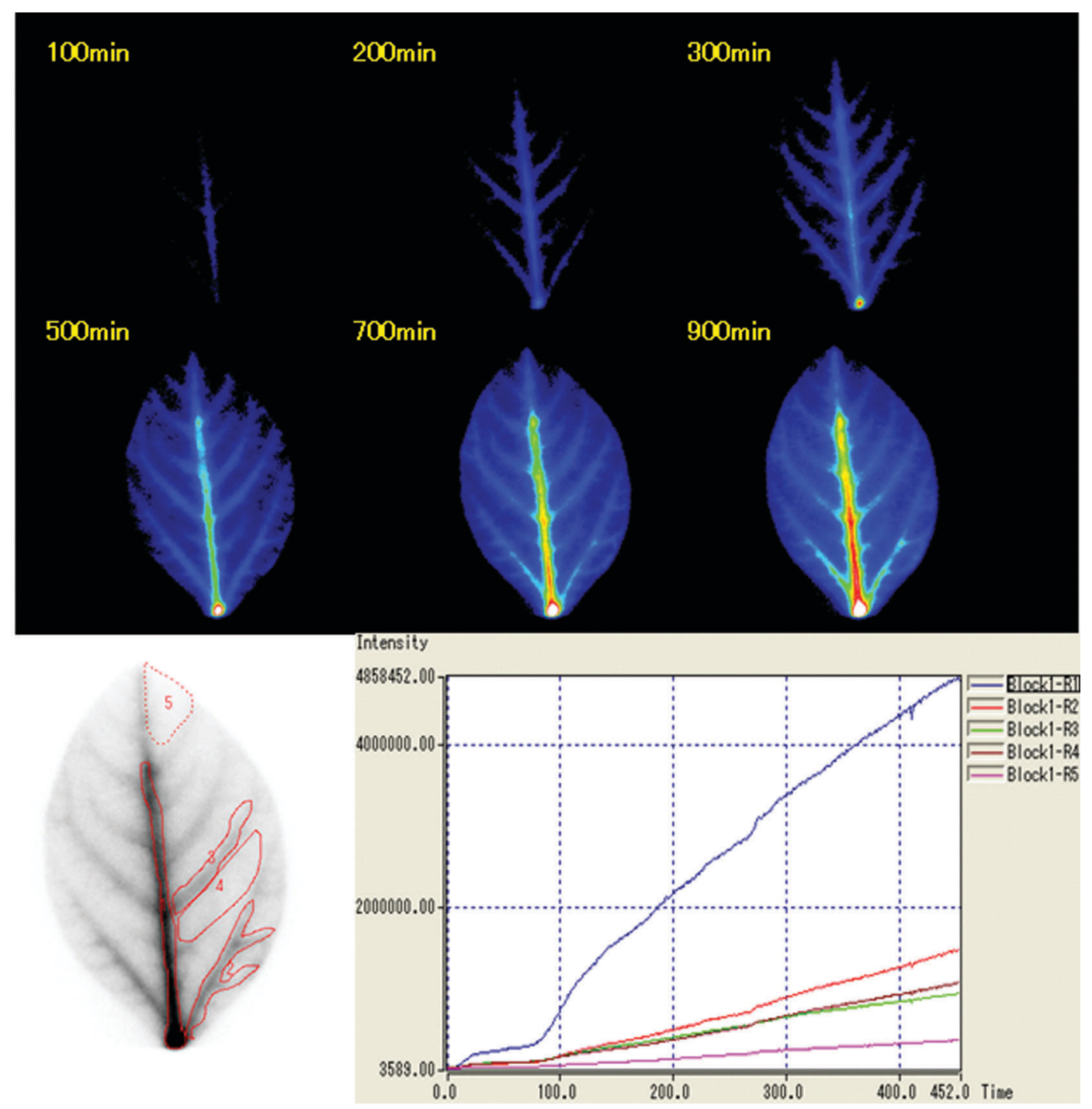

Fig. 8 An example of ${ }^{32} \mathrm{P}$ uptake analysis in a young soybean leaf by real-time autoradiography system.

the ${ }^{32} \mathrm{P}$ activity was accumulated mainly in the veins and the lower area of the leaf, and then, ${ }^{32} \mathrm{P}$ was gradually transported into mesophyll cells. As an example, some areas in the leaf were selected and the increasing manner of the radioactivity was plotted in Fig. 8 . As is shown in the figure, our system allowed to analyze the real-time movement of the radioisotope in a living plant.

\section{Conclusion}

Real-time autoradiography system we developed, was consisted of a FOS (a fiber optic plate deposited with CsI(Ti) scintillator) and a GaAsP imaging intensifier. The detection area was from $5 \mathrm{~cm} \times 5 \mathrm{~cm}$ up to $10 \mathrm{~cm} \times 20 \mathrm{~cm}$. Though the resolution of ${ }^{32} \mathrm{P}$ in the image was about the same as that of an imaging plate, 
May 2008 H. Rai et al. : Development of a real-time autoradiography system to analyze the movement of the compounds labeled with $\beta$-ray emitting nuclide in a living plant

about $100 \mu \mathrm{m}$, the sensitivity was more than 10 times higher than that of an IP for the same measurement time. Integration of the image, every 1 to 3 minutes, showed that it was able to perform real-time imaging of ${ }^{32} \mathrm{P}$ movement in a soybean plant. Since this system was developed for $\beta$-ray emitters, we are going to analyze the other nuclides such as ${ }^{14} \mathrm{C},{ }^{35} \mathrm{~S}$ or ${ }^{45} \mathrm{Ca}$ in a living plant.

\section{References}

1) Stumpf, W. E. and Solomon, H. F., Autoradiography and Correlative Imaging, pp. 3-42, Academic Press Inc., U.K. (1995)

2) Giovanni, M., Maria, C. and Paolo, R., Tritium digital autoradiography with a Medipix2 hybrid silicon pixel detector., Nucl. Instrum. Methods Phys. Res., Sect. A, 516, 554-563 (2004)

3) Barthe, N., Chatti, K., Coulon, P., Maîtrejean, S. and Basse-Cathalinat, B., Recent technologic developments on high-resolution beta imaging systems for quantitative autoradiography and double labeling applications, Nucl. Instrum. Methods
Phys. Res., Sect. A, 527, 1-2, 41-45(2004)

4) Kiyomiya, S., Nakanishi, H., Uchida, H., Tsuji, A., Nishiyama, S., Futatsubashi, M., Tsukada, H., Ishioka, N. S., Watanabe, S., Ito, T., Mizuniwa, C., Osa, A., Matsuhashi, S., Hashimoto, S., Sekine, T. and Mori, S., Real time visualization of ${ }^{13} \mathrm{~N}$-translocatioin in rice under different environmental condition using positron emitting tracer imaging system, Plant Physiol., 125, 1743-1754 (2001)

5) Nakanishi, T. M., Yokota, H., Tanoi, K., Ikeue, N., Ojuni, Y., Furukawa, J., Ishioka, N. S., Watanabe, S., Osa, A., Sekine, T., Matsuhashi, S., Ito, T., Kume, T., Uchida, H. and Tsuji, A., Comparison of ${ }^{15} \mathrm{O}$-labeled and ${ }^{18} \mathrm{~F}$-labeled water uptake in a soybean plant by PETIS(positron emitting tracer imaging system)., RADIOISOTOPES, 50, 265-269 (2001)

6) Bughio, N., Nakanishi, H., Kiyomiya, S., Matsuhashi, S., Ishioka, N. S., Watanabe, S., Uchida, H., Tsuji, A., Osa, A., Kume, T., Hashimoto, S., Sekine, T. and Mori, S., Real-time $\left[{ }^{11} \mathrm{C}\right]$ methionine translocation in barley in relation to mugineic acid phytosiderophore biosynthesis, Planta, 213, 708-715 (2001) 
要旨

\section{植物中の物質動態解析のための $\beta$ 崩壊核種を用いた}

リアルタイムオートラジオグラフィーシステムの開発

頼 泰樹*, 菅野里美*, 林 芳武*, 大矢智幸*, 二瓶直登 $*$, **, 中西友子*

*東京大学大学院 農学生命科学研究科 応用生命化学専攻 放射線植物生理学研究室

113-8657 東京都文京区弥生 1-1-1

**福島県農業総合センター

963-0531＼cjkstart福島県郡山市日和田町高倉字下中道 116

植物体の物質動態をリアルタイムで 2 次元的に解析できれば、植物の物質輸送、シグナル伝達の メカニズムをより詳細に明らかにすることが可能となる。そこで著者らは植物が生きたままの状態 で、取り込ませた $\beta$ 崩壊核種の RI 標識化合物をリアルタイムでイメージング可能なシステムを新 たに開発した。このリアルタイムオートラジオグラフィーシステムは CsI シンチレータをファイバ ープレートに蒸着したFOS とシングルフォトンを検出可能な超高感度カメラ GaAsP imaging intensifier で構成している。このシステムの解像度（視野 $5 \times 5 \mathrm{~cm}$ の場合）は Imaging Plate とほほ 同様であったが、単位時間あたりのラジオアイソトープの検出感度は 10 倍以上の高感度を示した。 このシステムを用いた大豆の ${ }^{32} \mathrm{P}$ 標識リン酸の吸収過程を画像解析した結果、葉の各部位における 経時的な濃度変化の解析結果を解析例として示した。 